\title{
Thermal stability and flame retardant properties of plasticized poly(vinyl chloride) hybrid composite for construction application
}

Ali I. AL-MOSAWI

PhD student in Polymers engineering Institute of Ceramic and Polymer Engineering, Faculty of Material Science and Engineering, University of Miskolc, Hungary. M.Sc. and B.Sc. Materials Engineering, Faculty of Engineering, University of Babylon, IRAQ. Research interests: Polymers, Composite materials, Rubber technology, Flame retardants, Material testing, Materials processing.

Au I. AL-MOSAWI - Institute of Ceramic and Polymer Engineering, University of Miskolc, Hungary - aliibrahim76@yahoo.com

KÁLMÁN MAROSSY - Institute of Ceramic and Polymer Engineering, University of Miskolc, Hungary - qkoali76@uni-miskolc.hu

Érkezett: 2019. 11. 29. - Received: 29. 11. 2019. " https://doi.org/10.14382/epitoanyag-jsbcm.2019.35

\section{Abstract}

Current research is investigating how to improve constructions efficiency and at the same time increase their fire resistance. Oxydtron is used as admixture for concrete to improve its properties, but Oxydtron has shown unpredictable behavior when used as filler for plasticised PVC where the flame retardation and stabilization at high temperatures of the polymer was improved after Oxydtron additions. Thermal tests were carried out to demonstrate the ability of Oxydtron to improve thermal resistance of the plasticised PVC and these tests included: Limiting oxygen index, Dehydrochlorination, and Dynamic mechanical analysis. The results of these tests proved the efficiency of Oxydtron as effective filler for plasticised PVC by increasing the flame retardation and thermal stability.

Keywords: thermal stabilizing, flammability, oxydtron, plasticized poly(vinyl chloride)

Kulcsszavak: hôstabilitás, éghetôség, oxydtron, lágyított PVC

\section{Introduction}

When Prometheus stolen the fire from the Hephaestus god of blacksmiths in Mount Olympus according to the Greek mythology and gave it to humans to help them overcome the difficulties of their daily lives related to heating, lighting and cooking; he didn't realize that fire would be useful to humans but also would bring destruction to them if they didn't use it safely. So, they have tried to find the methods to extinguish fire. Then they thought of something entirely new: creating materials that could resist fires reduce their risk and even completely stop it, thus, the concept of flame retreading appeared for the first time; and the subsequent discovery of materials (flame retardants) have the ability to break the cycle of fire [1,2]. As the concept of flame retardation developed, it was necessary to develop the way of thinking in this field; now, the search for new and unconventional materials in industry is imperative to balance environmental considerations for the safe use of non-polluting materials (or at least with limited damage) and to maintain the best possible achievement of new materials compared to traditional materials. Where the purpose is not only to use new engineering materials in the industry, but to be more efficient or at least maintain the same level of performance of the traditional materials currently available which can be termed metaphorically - the sustainability of properties - as with the sustainability of natural materials, otherwise there will be no benefit from Use of such materials [3-6]. Every year, fires cause a significant human and financial losses in all countries, and the proportion of these losses varies from one country to another depending on the equipment and techniques used to reduce the fires risk, as shown in Table 1 and Fig. 1, which are represented the economic-statistical evaluation of fire costs according to the center of fire statistics report issued in the year 2016 [7]. As shown in Table 1. Many countries still don't attach much importance to fire protection, but spend much of their gross domestic product (GDP) to extinguish the fires after ignite, but it is best to be concerned with how to prevent the fire from happening.

In general, the principle of reducing fire rates depends on the provision of conventional fire extinguishing equipment; use of materials with low flammability ranges or improve their thermal resistance if they are highly flammable such as polymers; appropriate design of the buildings to provide outlets to escape when the fire to reduce the loss of human, and all the above points are relevant to the important factor which is the deployment of a "fire prevention culture" that is fully dependent on people's awareness of fire hazards and the extent to which they apply safety arrangements to prevent fires or reduce it $[8,9]$. Poly (vinyl chloride) is one of the most important types of polymers used today in the plastics industry and has maintained its position in this industry despite its long discovery and the emergence of many new polymers due to its distinctive properties. Poly(vinyl chloride) can be produced in more than one state, which is rigid and flexible. The important thing is that changing poly(vinyl chloride) from rigid to flexible state there's no need to change its chemical formula through polymerization but through additives only, which is not available in the majority of other polymers. These additives improve many of the polymers properties in general, and one of these properties is thermal resistance, where all polymers not just poly(vinyl chloride) have low thermal resistance to high temperatures which considered an obstacle to the use of such materials in applications requiring high thermal resistance. Therefore, there is a high risk of using them in civil and industrial applications without increasing their resistance to combustion [3,10-20]. 


\begin{tabular}{|c|c|c|c|c|c|c|c|c|}
\hline \multirow[t]{3}{*}{$\mathbf{N}$} & \multirow[t]{3}{*}{ Country } & \multicolumn{5}{|c|}{ Cost in portion of GDP, \% } & \multirow{3}{*}{$\sum_{i=1}^{5} C_{i}$} & \multirow{3}{*}{$\begin{array}{c}\frac{\text { Expenditure }}{\text { losses }} \\
\frac{\mathrm{C} 3+\mathrm{C} 4+\mathrm{C} 5}{\mathrm{C} 1+\mathrm{C} 2}\end{array}$} \\
\hline & & \multirow{2}{*}{$\begin{array}{c}\text { Direct } \\
\text { losses } \\
\text { C }_{1}\end{array}$} & \multirow{2}{*}{$\begin{array}{c}\text { Indirect } \\
\text { losses } \\
\mathbf{C}_{2}\end{array}$} & \multirow{2}{*}{$\begin{array}{c}\text { Cost of fire } \\
\text { service } \\
C_{3}\end{array}$} & \multirow{2}{*}{$\begin{array}{c}\text { Fire protection } \\
\text { in buildings } \\
\text { C }_{4}\end{array}$} & \multirow{2}{*}{$\begin{array}{l}\text { Fire insurance } \\
\text { administrations } \\
\text { C }_{5}\end{array}$} & & \\
\hline & & & & & & & & \\
\hline 1 & Australia & 0.07 & - & 0.17 & - & - & - & - \\
\hline 2 & Czech Republic & 0.07 & - & - & 0.16 & - & - & - \\
\hline 3 & Finland & 0.17 & 0.011 & 0.19 & - & 0.03 & - & - \\
\hline 4 & France & 0.20 & - & - & - & - & - & - \\
\hline 5 & Germany & 0.12 & 0.014 & - & - & - & - & - \\
\hline 6 & Hungary & 0.02 & - & 0.13 & - & - & - & - \\
\hline 7 & Italy & 0.02 & - & - & 0.35 & 0.04 & - & - \\
\hline 8 & Japan & 0.12 & 0.060 & 0.26 & 0.12 & 0.09 & 0.650 & 2.61 \\
\hline 9 & Netherlands & 0.15 & - & 0.21 & 0.31 & - & - & - \\
\hline 10 & New Zealand & 0.12 & - & 0.16 & 0.24 & - & - & - \\
\hline 11 & Poland & 0.09 & - & 0.16 & - & - & - & - \\
\hline 12 & Singapore & 0.04 & 0.027 & 0.03 & 0.40 & 0.02 & 0.517 & 6.72 \\
\hline 13 & Spain & 0.08 & - & - & - & - & - & - \\
\hline 14 & Sweden & 0.18 & 0.060 & 0.13 & 0.20 & 0.05 & 0.620 & 1.58 \\
\hline 15 & UK & 0.13 & 0.008 & 0.20 & 0.29 & 0.10 & 0.728 & 3.84 \\
\hline 16 & USA & 0.10 & 0.007 & 0.29 & 0.29 & 0.12 & 0.807 & 6.54 \\
\hline & Avrg. & 0.12 & 0.027 & 0.18 & 0.26 & 0.05 & 0.652 & 3.40 \\
\hline
\end{tabular}

Table 1 Economic-statistical evaluation of fire costs [7] 1. táblázat Tüzesetek költségeinek gazdasági elemzése [7]

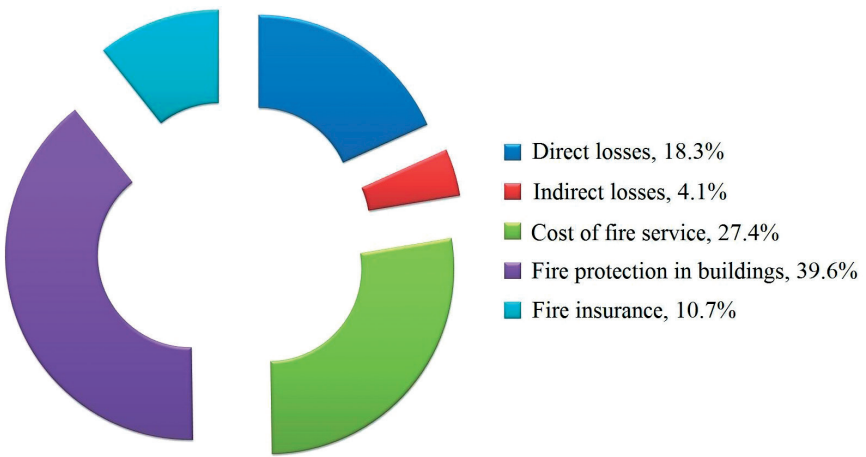

Fig. 1 Economic-statistical evaluation graph of fire costs [7]

1. ábra A tüzesetek költségeinek gazdasági elemzése [7]

Oxydtron one of the non-traditional additive that we used in this study. Those who hear about Oxydtron for the first time are thought to contain nanoparticles as indicated by the name but this is not true where the cement is a micro particles powder (about 2-3 $\mu \mathrm{m}$ ) and just the particle's coating layer which consists of modifier materials is nano size (from 10-100 nm); which gives this material special characteristics in addition to its low cost. Oxydtron contains many of the high-temperature oxides and carbonates that make it one of the most important and alternative options for conventional retardants used today [21-23].

\section{Methodology}

\subsection{Materials}

The raw materials used for producing tests samples illustrated in Table 2 which can be described as follows: (1) PVC S-5070 powder (under trademark Ongrovil ${ }^{\circledR}$ ) which produced and supplied by BorsodChem Zrt., Hungary; (2) the plasticizer DOP (Di-Octyl Phthalate) supplied by DEZA, a. s. CO.,
Valašské Meziřríčí, Czech Republic; (3) Calcium-Zinc based stabilizer (under trademark Newstab-50) which supplied by Betaquímica CO., Barcelona, Spain; (4) the lubricant Wax-E (under trademark Licowax ${ }^{\oplus} \mathrm{E}$ ) supplied by Clariant International Ltd, Muttenz Switzerland; and (5) Oxydtron (NC) (under trademark Oxydtron-Oxydtron type A) supplied by Bioekotech Hungary Kft.

\begin{tabular}{lcccccc} 
Component & \multicolumn{4}{c}{ PVC basic formulation } & $\begin{array}{c}\text { PVC } \\
\text { modifier }\end{array}$ \\
\cline { 2 - 6 } & PVC S-5070 & DOP & Newstab-50 & Wax-E & Oxydtron \\
pphr & 100 & 70 & 1.5 & 0.3 & $0-5$ (wt.\%)
\end{tabular}

Table 2 Raw materials for producing test samples and their dosage 2. táblázat Próbatestek készitéséhez használt alapanyagok és adagolásuk

\subsection{Materials processing}

The main mixing process involved mixing all the raw materials listed in Table 2, which accomplished using a mechanical mixer type MTI 10 Mischtechnik at $150{ }^{\circ} \mathrm{C}$; in order to obtain homogeneity in the mixture. After the main mixing process, the Oxydtron is added with the weight fraction $(0,1,3$, and 5$)$ wt.\%. The new hybrid blend has been mixed by small electric mixer to provide homogeneous distribution of Oxydtron within the poly(vinyl chloride) powder.

\subsection{Samples fabrication}

1. Limiting oxygen index samples: L.O.I samples were produced according to ISO 4589-2 standard [24] by using also laboratory two roll mill type Schwabenthan at the same processing conditions. A sheets with $0.4-0.6$ $\mathrm{mm}$ thickness made by rolling and then these sheets compressed by a hydraulic press type Bürkle at 300 and 20 bar pressure and $175^{\circ} \mathrm{C}$ to the desired L.O.I sample shape. 
2. Dehydrochlorination test: a particle of PVC and Oxydtron additives with the same dimensions of congo-red test was used in this test at $170{ }^{\circ} \mathrm{C}$ and according to ISO 182-3:1993 standard [25].

3. Dynamic mechanical analysis test: ISO 6721-11:2012 standard [26] was used to produce the samples. The DMA test samples were a strips fabricated by using extrusion machine type GÖTTFERT at $170{ }^{\circ} \mathrm{C}$ temperature and $60 \mathrm{rpm}$ speed at uniform conditions (pressure, temperature, and compression).

\subsection{The tests}

1. Limiting oxygen index test: This test was done at BorsodChem Zrt., Laboratory of Vinyl Technology by using Stanton Redcroft FTA flammability unit.

2. Dehydrochlorination test: Dehydrochlorination ranges have been measured by Metrohm 763 Thermomat device found also at BorsodChem Zrt., Hungary.

3. Dynamic mechanical analysis test: Dynamic mechanical thermal analyser MK III manufactured by Rheometric Scientific, Inc. and found at BorsodChem Zrt., Hungary, used for testing the samples. The temperature range is $-60{ }^{\circ} \mathrm{C}$ to $120^{\circ} \mathrm{C}$.

4. Scanning electron microscopy (SEM): In order to analyse the elemental composition and structure of Oxydtron, the Carl Zeiss EVO MA10 SEM was used for performed this analysis as shown in Fig. 2 and Table 3. SEM device found at Institute of Physical Metallurgy, Metal Forming and Nanotechnology, University of Miskolc, Hungary.

5. Oxides analysis: ICP-AES spectrometer was used for the analysis of Oxydtron components. The results of the analysis are listed in Table 4. ICP-AES spectrometer found at Institute of Chemistry, University of Miskolc, Hungary.

\begin{tabular}{ccccccc} 
Element & Wt.\% & At \% & $\begin{array}{c}\text { Net } \\
\text { Inte. }\end{array}$ & $\begin{array}{c}\text { Bkgd } \\
\text { Inte. }\end{array}$ & $\begin{array}{c}\text { Inte. } \\
\text { Error }\end{array}$ & P/B \\
$\mathrm{C}$ & 7.57 & 14.33 & 22.07 & 1.00 & 4.06 & 22.07 \\
\hline $\mathrm{O}$ & 34.78 & 49.43 & 121.40 & 1.50 & 1.68 & 80.93 \\
\hline $\mathrm{Na}$ & 0.64 & 0.63 & 6.53 & 3.87 & 10.56 & 1.69 \\
\hline $\mathrm{Mg}$ & 0.77 & 0.72 & 11.23 & 5.73 & 7.74 & 1.96 \\
\hline $\mathrm{Al}$ & 2.09 & 1.76 & 36.63 & 7.03 & 3.55 & 5.21 \\
\hline $\mathrm{Si}$ & 10.45 & 8.46 & 195.23 & 9.40 & 1.37 & 20.77 \\
\hline $\mathrm{S}$ & 1.48 & 1.05 & 27.37 & 9.90 & 4.58 & 2.76 \\
\hline $\mathrm{K}$ & 1.08 & 0.63 & 18.13 & 8.00 & 5.88 & 2.27 \\
\hline $\mathrm{Ca}$ & 38.85 & 22.04 & 563.83 & 7.70 & 0.78 & 73.23 \\
\hline $\mathrm{Ti}$ & 0.17 & 0.08 & 1.70 & 6.00 & 39.75 & 0.28 \\
\hline $\mathrm{Fe}$ & 2.12 & 0.86 & 12.63 & 3.67 & 6.46 & 3.45
\end{tabular}

Table 3 EDAX-SEM analyses for structural composition of Oxydtron 3. táblázat Az Oxydtron osszetételének SEM-EDAX analizise

\begin{tabular}{cc} 
Oxides & Ratio, wt.\% \\
$\mathrm{Al}_{2} \mathrm{O}_{3}$ & 4.47 \\
\hline $\mathrm{CaO}$ & 58.0 \\
\hline $\mathrm{Cr}_{2} \mathrm{O}_{3}$ & 0.006 \\
\hline $\mathrm{Fe}_{2} \mathrm{O}_{3}$ & 2.67 \\
\hline $\mathrm{K}_{2} \mathrm{O}$ & 0.78 \\
\hline $\mathrm{MgO}_{2}$ & 1.20 \\
\hline $\mathrm{Mn}_{2} \mathrm{O}_{3}$ & 0.05 \\
\hline $\mathrm{Na}_{2} \mathrm{O}$ & 0.31 \\
\hline $\mathrm{SO}_{3}$ & 2.50 \\
\hline $\mathrm{SiO}_{2}$ & 21.44 \\
\hline $\mathrm{TiO}_{2}$ & 0.274 \\
\hline $\mathrm{ZnO}$ & 0.138
\end{tabular}

Table 4 Chemical composition of Oxydtron analyzed by ICP-AES 4. táblázat Az Oxidtron kémiai osszetételének meghatározása ICP-AES módszerrel

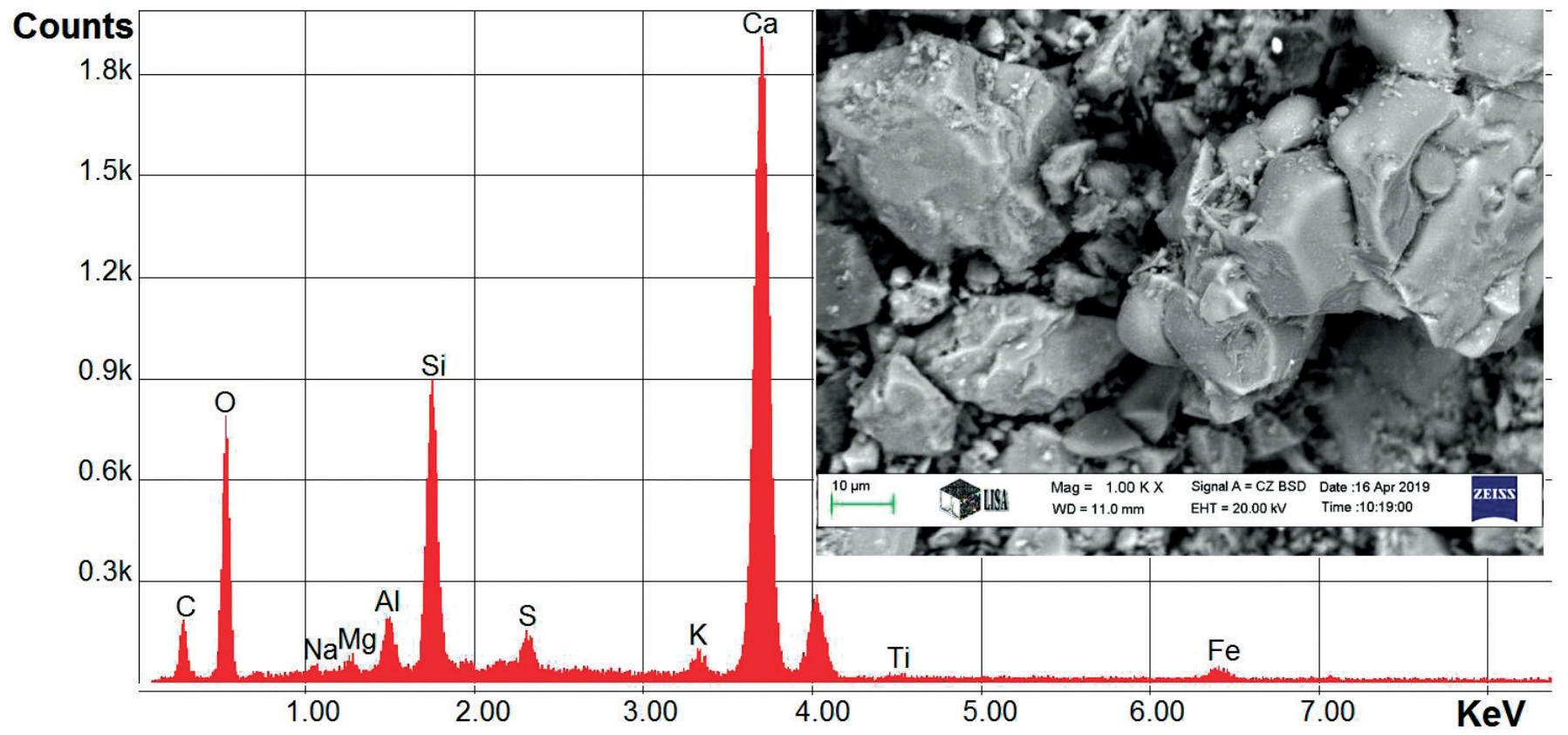




\section{Results and descussion}

Flame retarding results for plasticised PVC containing Oxydtron obtained by limiting oxygen index (L.O.I) test shown in Fig 3. From the first bar of this figure which represents the L.O.I. result of plasticised PVC basic formulation that the value of L.O.I is low (21.6\%). The low flame resistance considered a normal state for plastics and this low resistance because of the crystalline structure of these materials (especially organic) therefore it will ignite easily and rapidly when exposed to direct fire $[1,3]$. And in order to modify this critical behavior of plastics at high temperatures (PVC in this study), the additives are added to increase their thermal resistance. These additives can be used as fillers or coating layers [27,28]. After adding $1 \%$ Oxydtron as a new flame retardant additive for plasticised PVC fire resistance of the polymer improves as shown in the second bar of Fig. 3 where the L.O.I value has been increased to (22.3\%). The flame resistance of plasticised PVC is increasingly rising with increasing Oxydtron additives quantity which can be observed in the third bar of Fig. 3 which represents the L.O.I value of plasticised PVC containing 3\% Oxydtron where the L.O.I value reached to $(24.8 \%)$, while it will reach a value of (26.4\%) as shown in the fourth bar which represents L.O.I value of plasticised PVC containing 5\% Oxydtron. This unexpected behavior of Oxydtron stabilizing and flame retarding is due to Oxydtron composition which consists of many compounds such as calcium carbonate $\left(\mathrm{CaCO}_{3}\right)$ which considered a universal stabilizer for PVC and also silicon dioxide $\left(\mathrm{SiO}_{2}\right)$ in addition to many other compounds, and these two materials $\left(\mathrm{CaCO}_{3}\right.$ and $\mathrm{SiO}_{2}$ ) will act as a synergist agent with the Newstab-50 (original stabilizer) and creating additional stabilizing synergistic action causing increased thermal resistance and stability of plasticised PVC. Also, the calcium carbonate considered a flame retardant agent and its presence within the Oxydtron composition will help to increase the flame resistance of PVC.

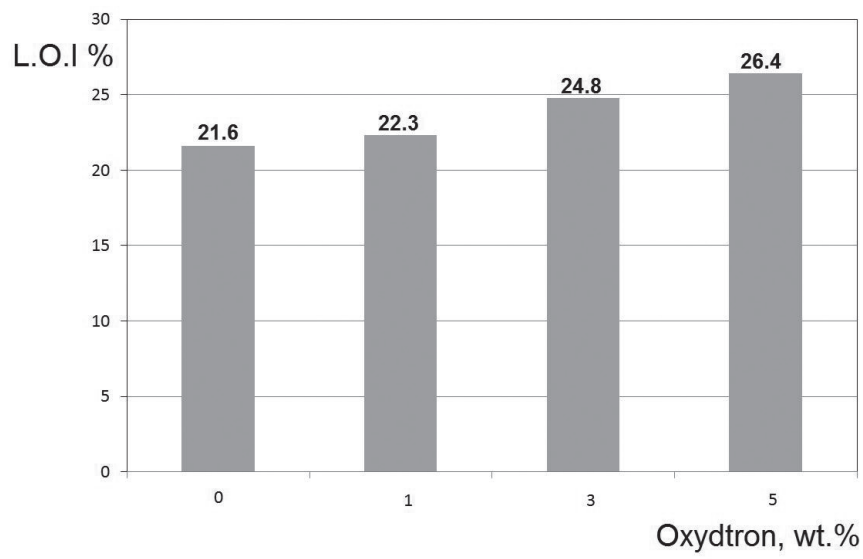

Fig. 3 Limiting oxygen index (L.O.I) values for plasticised PVC-Oxydtron hybrid composite

3. ábra Az Oxidtron tartalmú lágy PVC keverékek oxygen indexe (LOI)

The crystalline structure of PVC tends to release chlorine containing compounds strongly at high temperatures, as shown in Fig. 4, which represents a dehydrochlorination test for plasticised PVC basic formulation at $170{ }^{\circ} \mathrm{C}$; where the chlorine containing compounds loss is very rapid and the slope of the curve is very sharp (high inclination). This is a normal behavioure for PVC due to the low thermal resistance in high temperatures (for polymers) and this resistance decreases as the release of chlorine containing compounds increases where the crystalline structure of PVC is strongly deformed; and the bonds between atoms begin to break down and huge amounts of chlorine containing compounds are released [29]. This is observed from the high slope of the curve (0.000134) and at this point, the PVC reached the degree of total degradation.

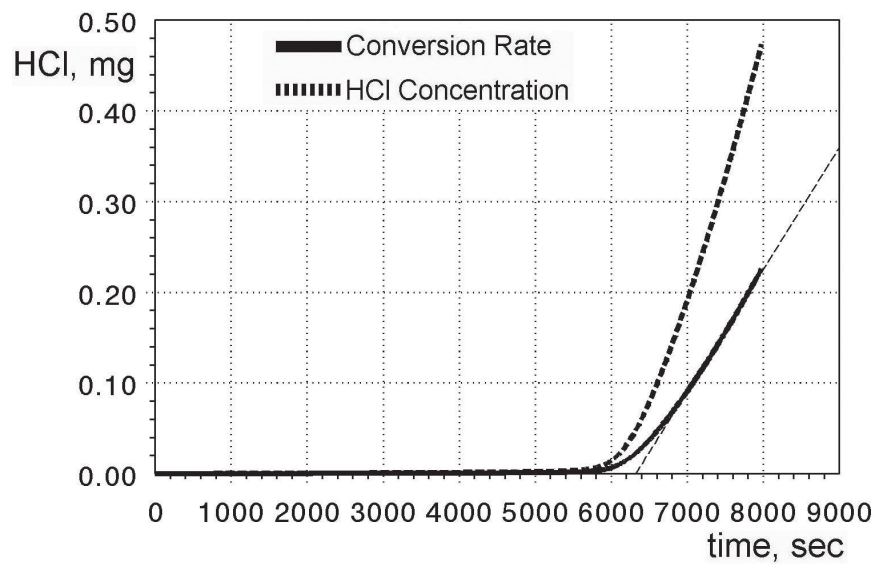

Fig. 4 Dehydrochlorination test of plasticised PVC basic formulation at $170^{\circ} \mathrm{C}$ 4. ábra A PVC alapreceptúra sósavlehasadás vizsgálata $170{ }^{\circ} \mathrm{C}$-on

Plasticised PVC becomes more resistant to high temperatures after of Oxydtron addition, as shown in Fig. 5 which represents the dehydrochlorination results of plasticised PVC containing $1 \%$ Oxydtron at $170{ }^{\circ} \mathrm{C}$; where the slope of the conversion rate curve decreased from (0.000134) in case of plasticised PVC basic formulation (without additive) to (0.000073) after Oxydtron addition, where the tendency of plasticised PVC to release chlorine containing compounds has been reduced and increased thermal stability and degradation resistance accompanied by extended degradation time range for plasticised PVC basic formulation from (2.21 hours) to (4.75 hours) after $1 \%$ Oxydtron addition. When the weight fraction of Oxydtron additives increases the thermal resistance stability of plasticised PVC will rise and this behavior can be distinguished by the Fig. 6 and Fig. 7 which represent the dehydrochlorination results of plasticised PVC containing 3\% and $5 \%$ Oxydtron at $170{ }^{\circ} \mathrm{C}$ respectively. From these figures, we notice that the slope of conversion rate curve will decrease, i.e. the degradation resistance has been increased, where in case of of 3\% Oxydtron content the slope of conversion rate curve becomes $(0.000062)$ with an increase in the total degradation time to (4.84 hours), and in case of of 5\% Oxydtron content the slope of conversion rate curve will reduce to $(0.000053)$ and increasing the total degradation time to (5.20 hours).

From Fig. 8 which represent the Dynamic Mechanical Analysis (DMA) for plasticised PVC-Oxydtron hybrid composite, we can note that the Oxydtron additives increase the glass transition temperature ( $\mathrm{Tg}$ ), where the glass transition temperature shifts to higher temperatures rising from $\left(-3.26^{\circ} \mathrm{C}\right)$ in case of plasticised PVC basic formulation to $\left(0.30^{\circ} \mathrm{C}\right)$ when $1 \%$ of Oxydtron has been added and continues to rise to $\left(3.50{ }^{\circ} \mathrm{C}\right)$ and $\left(4.66{ }^{\circ} \mathrm{C}\right)$ when added $3 \%$ and $5 \%$ of Oxydtron respectively. Clearly, there is an interaction between 
PVC and Oxydtron molecules, which causes the reduction of kinetic energy of plasticised PVC, and reducing the segmental movement, which probably prevents the molecules from assembling in crystalline systems, so the relaxation time of this movement increases. So the polymer will consist of long physically crosslinked liquid-like molecules [30].

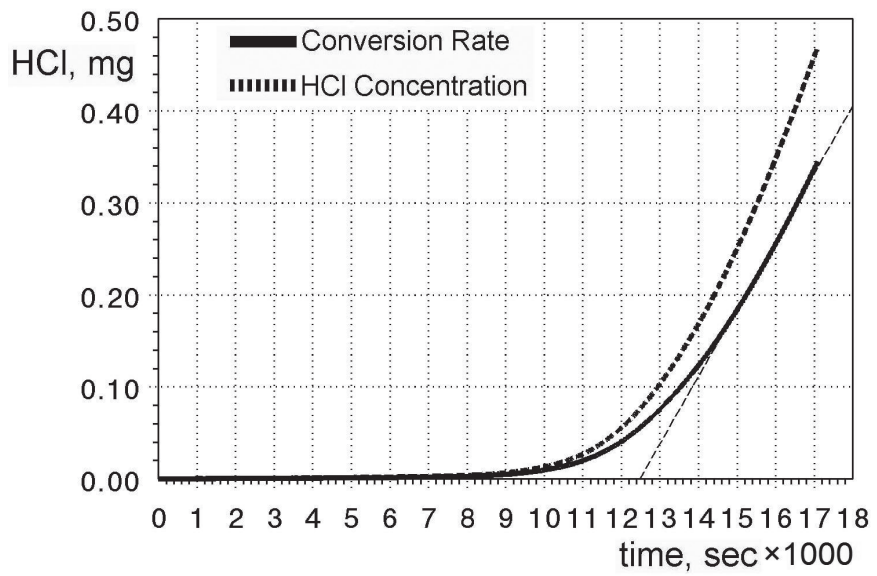

Fig. 5 Dehydrochlorination results of plasticised PVC containing $1 \%$ Oxydtron at $170{ }^{\circ} \mathrm{C}$ 5. ábra Az 1\% Oxidtron tartalmú lágy PVC sósavlehasadás vizsgálata $170^{\circ} \mathrm{C}$-on

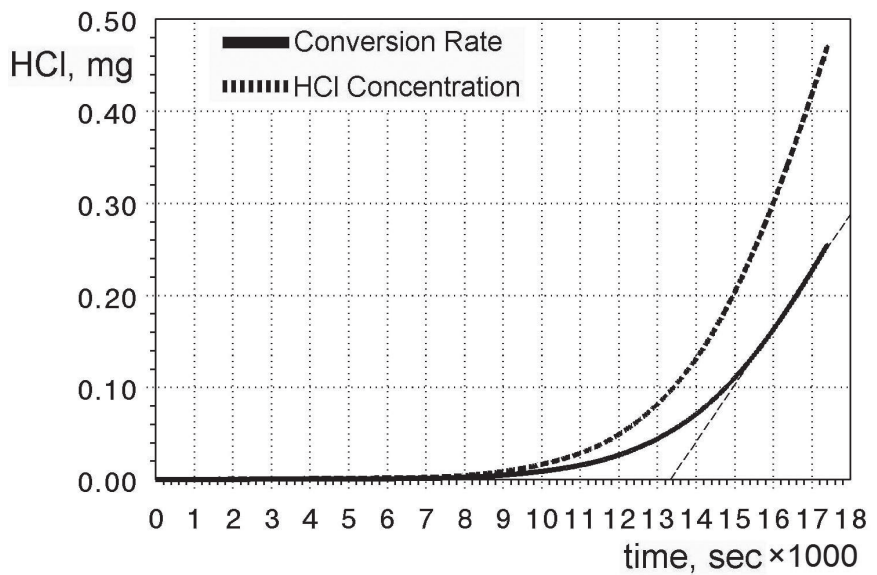

Fig. 6 Dehydrochlorination results of plasticised PVC containing $3 \%$ Oxydtron at $170{ }^{\circ} \mathrm{C}$ 6. ábra A $3 \%$ Oxidtron tartalmú lágy $P V C$ sósavlehasadás vizsgálata $170{ }^{\circ} \mathrm{C}$-on

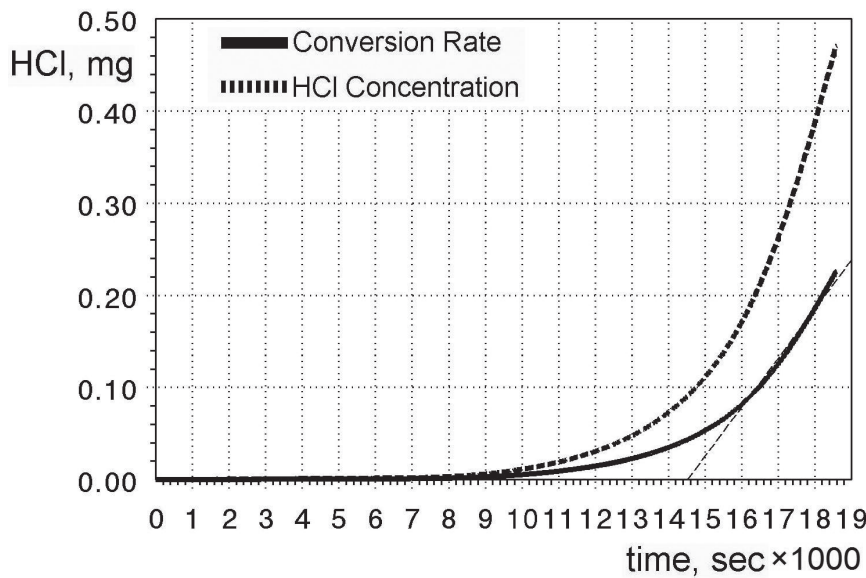

Fig. 7 Dehydrochlorination results of plasticised PVC containing $5 \%$ Oxydtron at $170{ }^{\circ} \mathrm{C}$ 7. ábra Az 5\% Oxidtron tartalmú lágy PVC sósavlehasadás vizsgálata $170{ }^{\circ} \mathrm{C}$-on

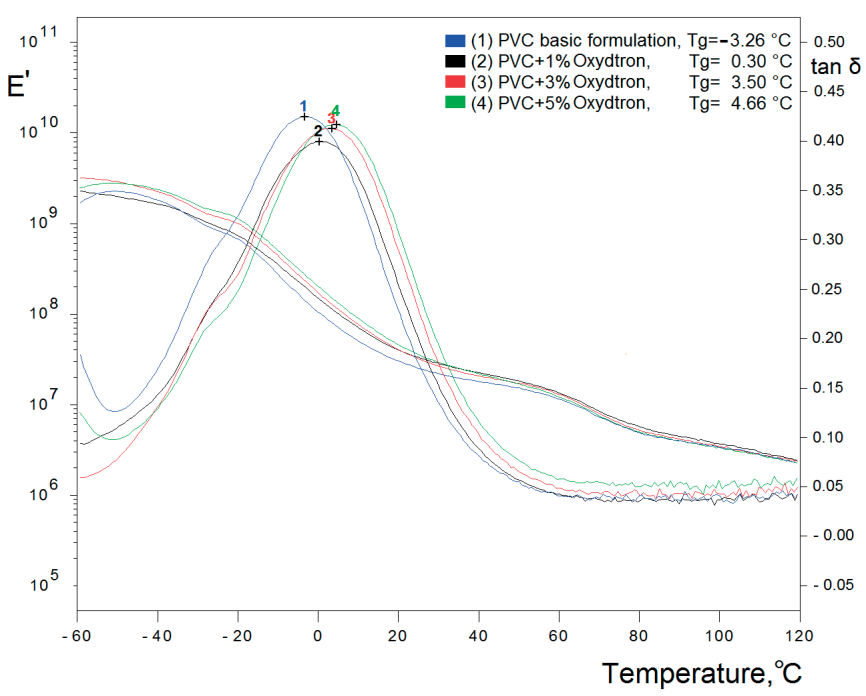

Fig. 8 Dynamic mechanical analysis for plasticised PVC-Oxydtron hybrid composite 8. ábra A lágy PVC-Oxidtron hybrid kompozitok dinamikus mechanikai analízise

\section{Conclusions}

In general, Oxydtron improves the thermal properties of plasticised PVC, where the enhancement of L.O.I value reached to $(22.22 \%)$ at $5 \%$ Oxydtron content. The degradation rate of plasticised PVC also decreased after adding Oxydtron, where the improvement of time required for total degradation with plasticised PVC containing 5\% Oxydtron was (135.30\%) longer than plasticised PVC basic formulation. Glass transition temperature was shifted towards higher temperatures after Oxydtron addition, and this indicates that Oxydtron directly affects kinetic energy and segmental movement of plasticised PVC causing to decrease them.

\section{References}

[1] Al-Mosawi, A.I. - Marossy, K. (2018): Heat effected zone in unburned, antimony trioxide containing plasticized poly(vinyl chloride), ÉpítőanyagJournal of Silicate Based and Composite Materials, Vol.70, No.3, pp.86-89. https://doi.org/10.14382/epitoanyag-jsbcm.2018.16

[2] Dowden, K. (2016): Prometheus, Oxford Research Encyclopedias. https:// 10.1093/acrefore/9780199381135.013.5363

[3] Al-Mosawi, A.I. (2016): Flammability of Composites, Chapter 14 in J. Njuguna (ed.) Lightweight composite structures in transport: Design, manufacturing, analysis and performance, Woodhead Publishing, UK, pp. 361-369. https://doi.org/10.1016/B978-1-78242-325-6.00014-1

[4] Al-Mosawi, A.I. - Rijab, M.A. - Salaman, A.J. - Alwash, N.A. - Aziz, N.S. (2012): Flammability Behavior of Composite Mixed with Retardant Agents, Applied Mechanics and Materials, Vol. 186, pp. 129-131. https://doi.org/10.4028/www.scientific.net/AMM.186.129

[5] Al-Maamori, M.H. - Al-Mosawi, A.I. - Hashim, A.A. (2011): Flame Retardancy Enhancement of Hybrid Composite Material by Using Inorganic Retardants, Materials Sciences and Applications, Vol.2, No.8, pp. 1134-1138. https://doi.org/10.4236/msa.2011.28153

[6] Al-Mosawi, A.I. - Ahmed, J.K. - Hussain, H.A. (2012): Evaluation Flame Retardancy of Epoxy Composite by Using Design of Experiments, Applied Mechanics and Materials, Vol. 186, pp. 156-160. https://doi.org/10.4028/www.scientific.net/AMM.186.156

[7] Brushlinsky, N. - Ahrens, M. - Sokolov, S. - Wagner, P. (2016): World fire statistics, Report No.21, International association of fire and rescue services, Center of fire statistics.

[8] Fire Research Report (2012): Comparison of European Fire Statistics, Final report for the Department for Communities and Local Government, Eland House, London, UK. 
[9] Winberg, D. (2016): International Fire Death Rate Trends, SP Technical Research Institute of Sweden, Report No.32

[10] Al-Mosawi, A.I. - Marossy K. (2019): Effect of Extrusion Speed and ATO Content on Rheological Properties of Plasticised PVC, IOP Conf. Ser.: Mater. Sci. Eng., Vol.613, pp.1-5 (012029). https://doi.org/10.1088/1757-899X/613/1/012029

[11] Al-Mosawi, A.I. - Marossy, K. (2019): Processing Conditions and Their Effect on Homogeneity of PPVC Structural Characteristics, ARPN Journal of Engineering and Applied Sciences, Vol.14, No.14, pp.2485-2491.

[12] Al-Mosawi, A.I. - Marossy, K. (2018): Performance Evaluation of Mixing Mechanism and its Effects on Thermal Behaviour of Plasticised PVC, International Journal of Engineering and Technology (IJET),Vol. 9,No. 6, pp.4389- 4396. https://doi.org/10.21817/ijet/2017/v9i6/170906130

[13] Al-Mosawi, A.I. - Marossy, K. - Kónya, C. (2018): Effect of Plasticizer Percentage on Thermal Properties of Plasticised PVC, Elixir International Journal,Vol. 117,pp.50509-50511.

[14] Al-Mosawi, A.I. - Al-Zubadi, A.A. - Al-Maamori , M.H. - Al-Maimuri, N.M. (2013): Fire Retardants for Civil Structures, Global Journal of Researches in Engineering: C, Chemical Engineering, Vol.13, Issue.2, pp. 8-12.

[15] Hull, T.R. - Witkowski, A. - Hollingbery, L. (2011): Fire Retardant Action of Mineral Fillers, Polymer Degradation and Stability, Vol.96, Issue.8, pp.1462-1469. https://doi.org/10.1016/j.polymdegradstab.2011.05.006

[16] Li, M. - Zhang, J. - Huang, K. - Li, S. - Jianga, J. - Xia, J. (2014): Mixed Calcium and Zinc Salts of Dicarboxylic Acids Derived from Rosin and Dipentene: Preparation and Thermal Stabilization for PVC, RSC Advances, Vol.4, 2014, pp.63576-63585. https://doi.org/10.1039/C4RA10657A

[17] Jiao, Y. - Wang, X. - Peng, F. - Xu, J. - Gao, J. - Meng, H. (2014): Increased Flame Retardant, Smoke Suppressant and Mechanical Properties of SemiRigid Polyvinyl Chloride (PVC) Treated with Zinc Hydroxystannate Coated Dendritic Fibrillar Calcium Carbonate, Journal of Macromolecular Science, Part B: Physics, Vol.53, Issue.3, pp.541-554 https://doi.org/10.1080/00222348.2013.852061

[18] Asawakosinchai, A. - Jubsilp, C. - Mora, P. - Rimdusit, S. (2017): Organic Heat Stabilizers for Polyvinyl Chloride (PVC): A Synergistic Behavior of Eugenol and Uracil Derivative, Journal of Materials Engineering and Performance, Vol.26, Issue.10, pp.4781-4788. https://doi.org/10.1007/s11665-017-2923-0

[19] Liu, P. - Zhao, M. - Guo, J. (2006): Thermal Stabilities of Poly(Vinyl Chloride)/Calcium Carbonate $\left(\mathrm{PVC} / \mathrm{CaCO}_{3}\right)$ Composites, Journal of Macromolecular Science, Part B: Physics, Vol.45, Issue.6, pp.1135-1140. https://doi.org/10.1080/00222340600962650

[20] Grossman, R.F. (2008): Handbook of Vinyl Formulating, $2^{\text {nd }}$ edition, Wiley series on plastics engineering and technology, John Wiley \& Sons, Inc. publication, New Jersey USA. https://doi.org/10.1002/9780470253595
[21] Bioekotech (2014): Oxydtron Nanocement, Cement Quality Improving Admixture, BIOEKOTECH Hungary KFT.

[22] Dunuweera, S.P., Rajapakse, R.M.G. (2018): Cement Types, Composition, Uses and Advantages of Nanocement, Environmental Impact on Cement Production, and Possible Solutions, Advances in Materials Science and Engineering, Vol.2018, pp. 1-11 (ID 4158682). https://doi.org/10.1155/2018/4158682

[23] Merlin, F. - Lombois, H. - Joly, S. - Lequeux, N. - Halary, J. - Van Damme, H. (2002): Cement-Polymer and Clay-Polymer Nano- and MesoComposites: Spotting the Difference, Journal of Materials Chemistry, Vol. 12, No. 11, pp. 3308-3315. https://doi.org/10.1039/B205279M

[24] ISO 4589-2 (2017): Plastics - Determination of burning behavior by oxygen index - Part 2: Ambient-temperature test, International Organization for Standardization (ISO).

[25] ISO 182-3 (1993): Plastics-Determination of the tendency of compounds and products based on vinyl chloride homopolymers and copolymers to evolve hydrogen chloride and any other acidic products at elevated temperatures-Part 3: Conductometric method, International Organization for Standardization (ISO).

[26] ISO 6721-11 (2012): Plastics-Determination of dynamic mechanical properties - Part 11: Glass transition temperature, International Organization for Standardization (ISO).

[27] Hobbs, C.E. (2019): Recent Advances in Bio-Based Flame Retardant Additives for Synthetic Polymeric Materials, Polymers, Vol. 11, Issue.2, pp. 1-31. https://doi.org/10.3390/polym11020224

[28] Al-Mosawi, A.I., Marossy, K. (2018): L.O.I and DSC Analyses of Antimony Trioxide Containing Plasticized PVC as a Function of Processing Method, MultiScience - XXXII. microCAD International Multidisciplinary Scientific Conference, University of Miskolc, Hungary, 5-6 September, pp.1-5. https://doi.org/10.26649/musci.2018.017

[29] Zheng, X-G., Tang, L-H., Zhang, N., Gao, Q-H., Zhang, C-F., Zhu, Z-B. (2003): Dehydrochlorination of PVC Materials at High Temperature, Energy and Fuels, Vol.17, Issue.4, pp. 896-900. https://doi.org/10.1021/ef020131g

[30] Marossy, K. (2006): Testing polymer mixtures by Dynamic Mechanical Analysis, Manuscript of a lecture: Hungarian Academy of Sciences.

$\underline{\text { Ref:: }}$

Al-Mosawi, A.I. - Marossy, Kálmán: Thermal stability and flame retardant properties of plasticized poly(vinyl chloride) hybrid composite for construction application

Építőanyag - Journal of Silicate Based and Composite Materials, Vol. 71, No. 6 (2019), 198-203. p. https://doi.org/10.14382/epitoanyag-jsbcm.2019.35

\section{European}

Composite Materials congress

Biosensors and Bioelectronic Materials Symposium Graphene and 2D Materials Conference

\section{9 - 11 June 2020 | Stockholm, Sweden}

Venue: M/S Mariella, Viking Line Cruise Ship

Stockholm (Sweden) - Helsinki (Finland) - Stockholm (Sweden)

www.advancedmaterialscongress.org/cmc20
The multi-inter-trans-disciplinary Research, Innovations and Technology 